\title{
Refractory High Grade Burkitt-Like Lymphoma
}

National Cancer Institute

\section{Source}

National Cancer Institute. Refractory High Grade Burkitt-Like Lymphoma. NCI

Thesaurus. Code C5003.

High grade B-cell lymphoma Burkitt-like lymphoma resistant to treatment. 